\title{
SABER LER LIVROS (E O MUNDO) É UMA HABILIDADE LIBERTADORA
}

\author{
Ana Carla Campregher da Silva ${ }^{1}$
}

Resumo: Este artigo tem como objetivo evidenciar a importância da leitura de mundo como componente do processo de letramento feito na escola, sendo importante ferramenta para a construção de cidadãos críticos do mundo e de seu papel nele. Isso é feito através da análise literária de duas obras, Cobertor de Estrelas, de Ricardo Lísias e Each Kindness, de Jacqueline Woodson, tendo como principais enfoques os elementos narrador, espaço e as imagens como parte componente da obra para construção de significado. As análises feitas são amostras das perspectivas que podem ser tomadas dentro de uma proposta escolar de leitura, uma vez que a leitura de textos literários é poderosa oportunidade de diálogo e reflexão acerca do mundo, de como ele se estrutura hierarquicamente e como essa estrutura poderia ser outra.

Palavras-chave: Letramento. Análise Literária. Leitura de mundo.

"Não há povo e não há homem que possa viver sem ela, isto é, sem a possibilidade de entrar em contato com alguma espécie de fabulação." (CANDIDO, 2004, p. 174). A arte de fabular, contar histórias, pensar saídas, alternativas, fingir ser outra pessoa, ou ainda outro ser, é habilidade inerente ao ser humano e, portanto, não deve ser negada, pois ajuda seres humanos a entenderem o mundo e a si mesmos. Contudo, fabular não está necessariamente ligado ao ato de escrever ou ler histórias: é habilidade desenvolvida antes mesmo da alfabetização.

Paulo Freire afirma que "a leitura do mundo precede sempre a leitura da palavra e a leitura desta implica na continuidade da leitura daquele." (FREIRE, 1981, p.29). Em outras palavras, o processo de letramento de uma pessoa não começa quando ela passa a associar letras a sons e atribuir esses sons à coisas, mas desde o momento em que ela percebe sensorialmente o mundo a sua volta e o interpreta em relação a suas experiências pessoais de vida. Dessa maneira, a leitura do mundo precede a leitura das palavras, e a leitura de palavras nunca deve estar dissociada da leitura do mundo.

$\mathrm{Na}$ hierarquia das sociedades grafocêntricas, as habilidades de ler e escrever desempenham papel crucial no estabelecimento de posições sociais: as pessoas que sabem ler e escrever têm mais oportunidades de trabalho, de

\footnotetext{
${ }^{1}$ Bacharel em Letras Inglês, graduanda em Licenciatura Letras Inglês pela UFPR. Trabalha em âmbito educacional há 6 anos, tendo atuado sobretudo na área de ensino de Inglês como Língua Adicional e no ambiente de escolas internacionais.
} 
ascensão social, de voz política e de ser neste mundo. Não são apenas habilidades de inserção numa estrutura social pré-determinada, mas habilidades para sua ampliação e contestação. Segundo a antropóloga Michèle Petit, cuja visão sobre leitura partilha dos traços sociais que Freire postula, por meio da leitura as pessoas podem "(...) ir mais longe do que a programação social poderia levá-los." (PETIT, 2008, p. 99).

O poder emancipatório que a leitura traz ao ser humano, pode ser, contudo, instrumento perigoso de manutenção de poder. No âmbito da instrução escolar o livro chega a gerar conflitos, porque seus efeitos extrapolam normas estabelecidas (CANDIDO, 2004). Ao refletir sobre as diferentes concepções de letramento, Magda Soares discorre sobre a concepção revolucionária de letramento, que ela define da seguinte maneira:

\footnotetext{
$\mathrm{Na}$ interpretação radical, "revolucionária", letramento não pode ser considerado um "instrumento" neutro a ser usado nas práticas sociais quando exigido, mas é essencialmente um conjunto de práticas socialmente construídas que envolvem a leitura e a escrita, geradas por processos sociais mais amplos, e responsáveis por reforçar ou questionar valores, tradições e formas de distribuição de poder presentes nos contextos sociais. (SOARES, 2003, p.75)
}

Nesse sentido, a leitura tem o poder de criar caminhos para ascensão na hierarquia social, uma vez que ler não só traz conhecimento de mundo, mas impulsiona o indivíduo a desenvolver habilidades de pensamento crítico, questionador. "A literatura pode ser um instrumento consciente de desmascaramento, pelo fato de focalizar as situações de restrição dos direitos, ou de negação deles, como a miséria, a servidão, a mutilação espiritual." (CANDIDO, 2004, p.186). É nesse sentido que a leitura crítica da realidade, dando-se num processo de alfabetização e associada sobretudo a certas práticas claramente políticas de mobilização e de organização, pode constituir-se num instrumento para o que Gramsci chamaria de ação contra-hegemônica. (FREIRE, 1981, p.31) Em outras palavras, a leitura crítica da realidade e do mundo possibilita ao ser humano lutar contra as hegemonias, sejam elas de classe, raça ou gênero.

Através do letramento crítico, dentro do qual está o estudo crítico de literaturas, pessoas podem tornar-se cidadãs conscientes do mundo a sua volta, de seu lugar nele, e das suas condições de mobilidade e de revolução social. 
Referimo-nos especialmente ao estudo de literaturas por concordarmos com a afirmação de Michèle Petit:

Estou convencida de que a leitura, em particular a leitura de livros, pode ajudar os jovens a serem mais autônomos e não apenas objetos de discursos repressivos ou paternalistas. E que ela pode representar uma espécie de atalho que leva de uma intimidade um tanto rebelde à cidadania. (PETIT, 2008, p.19)

As artes num sentido amplo (música, filme, dança, cinema) permitem a prática da alteridade e de encontrar-se no outro; histórias partilhadas no mundo inteiro, em prosa e verso, pintura ou movimento, das mais diversas épocas e países, de alguma forma unem pessoas à condição humana. Referindo-se especialmente à literatura, o escritor Mario Vargas Llosa afirma,

\footnotetext{
Nada defende melhor os seres vivos contra a estupidez dos preconceitos, do racismo, da xenofobia, das obtusidades localistas do sectarismo religioso ou político, ou dos nacionalismos discriminatórios, do que a comprovação constante que sempre aparece na grande literatura: a igualdade essencial de homens e mulheres em todas as latitudes e a injustiça representada pelo estabelecimento entre eles de formas de discriminação, sujeição ou exploração. (LLOSA, 2009, p.2)
}

O papel da escola na formação de leitores críticos é crucial (sobretudo em países como o Brasil, onde bibliotecas públicas são raras e o letramento de adultos é limitado), pois é na escola que as crianças são, na sua maioria, introduzidas ao mundo das letras, dos livros, das histórias. O letramento crítico capacita o indivíduo a olhar para dentro de si e para fora, percebendo-se membro de diversos grupos no mundo, e essa consciência é crucial para a tentativa de transformação das relações sociais, idealmente em busca de tolerância, democracia e justiça. Freire associa essa noção de pertencimento no mundo com a prática educativa:

Um outro ponto que me parece interessante sublinhar, característico de uma visão crítica da educação, portanto da alfabetização, é o da necessidade que temos, educadoras e educadores, de viver, na prática, o reconhecimento óbvio de que nenhum de nós está só no mundo. (FREIRE, 1981, p.37) 
Portanto, a maneira como uma escola concebe leitura e formação de leitores pode dar a toda uma geração de indivíduos a faculdade de questionar padrões e alterar realidades, como pode também reafirmar estruturas de poder no mundo, e doutrinação de pensamentos que asseguram a manutenção de vertentes político-filosóficas no poder. "Quanto mais formos capazes de nomear o que vivemos, mais aptos estaremos para vivê-lo e transformá-lo" (PETIT, 2008, p.71). Nesse sentido, a escola tem a oportunidade de tornar o mundo mais inteligível, e consequentemente mais questionável aos olhos dos alunos, cuja participação cidadã se amplia por meio do letramento.

Com essa perspectiva do poder de transformação social através do letramento crítico, este estudo pretende analisar duas obras literárias que instigam reflexões a respeito do fazer-literário, que possibilitam discussões profundas acerca de temáticas sociais relevantes à formação de cidadãos conscientes de si e do mundo. As obras escolhidas são narrativas que tratam de questões sociais comuns a muitas sociedades contemporâneas, como também a sociedades de épocas diferentes.

Cobertor de estrelas (1999), primeiro romance do brasileiro Ricardo Lísias, narra a vida de um menino de rua em uma cidade grande, acompanhando suas experiências cotidianas e permitindo a percepção sensível de suas dores, angústias, alegrias e desejos. Each Kindness (2012), narrativa infantil da norteamericana Jacqueline Woodson, narra a história de Maya, uma garota recém admitida em uma escola, e Chloe, a narradora, que conta suas experiências sobre o que aprendeu com a chegada de Maya na escola e em sua vida. Com exceção de alguns marcadores de clima que aparecem em ambas as obras (em Cobertor de Estrelas sabe-se que as noites às vezes são muito frias, e em Each Kindness sabe-se que em certo período do ano neva), são histórias de certa forma transferíveis para diversas realidades culturais, pois tratam de assuntos como pobreza, exclusão, solidão, ilusão, violência, necessidades vitais, tópicos inerentes a possivelmente todos os seres humanos, ainda que em sociedades diferentes.

As análises literárias a seguir procuram se debruçar sobre o foco narrativo e o espaço de cada obra, com o objetivo de expandir horizontes sobre reflexões acerca das obras literárias, para que não se limitem dentro do campo de 
discussão da temática social, mas que, melhor, sejam interpretadas dentro de sua complexidade e subjetividade e discutidas através da reflexão sobre elementos que Ihes são estruturantes. Esta análise tem por propósito, então permitir uma compreensão mais profunda acerca dos temas humanos de cada narrativa.

\section{Narradores em Cobertor de Estrelas, por Ricardo Lísias}

Cobertor de Estrelas ${ }^{2}$ é uma narrativa de ficção realista sobre meninos de rua. Predomina na obra o narrador onisciente seletivo, que, dentro da tipologia de Norman Friedman, "É, como no caso do narrador-protagonista, a limitação a um centro fixo. O ângulo é central, e os canais são limitados aos sentimentos, pensamentos e percepções da personagem central, mostrados diretamente." (LEITE, 1987, p.57). Em outras palavras, a narrativa é contada por um narrador onisciente, a partir do ponto de vista do protagonista, expresso por meio do discurso indireto livre. É importante ressaltar que este é o foco predominante e não o exclusivo na obra, pois, como afirma Leite, "trata-se sempre de uma questão de predominância e não de exclusividade, já que é difícil encontrar, numa obra de ficção, especialmente quando ela é rica em recursos narrativos, qualquer uma dessas categorias em estado puro." (LEITE, 1987, p.26). Esse dado é relevante para a análise da obra, uma vez que a personagem central é complexamente construída a partir dessa estratégia narrativa, mostrando-se como personagem que, apesar de não ter nome próprio, possui identidade singular profundamente construída: o menino pensa e tem opinião sobre tudo que vê e todos com quem se relaciona, mesmo sendo narrado em terceira pessoa. Ou seja, a voz da personagem central se mescla com a voz do narrador, ao ponto de em alguns momentos o leitor talvez não saber quem fala, o narrador ou o menino. Esse recurso narrativo também atrai o leitor para muito perto da personagem central; como se possuísse uma lupa perscrutadora e analítica, o narrador onisciente seletivo põe à mostra os pensamentos, sensações, desejos e anseios da personagem.

A obra narra o dia-a-dia "cíclico" de um menino de rua, através de sua própria perspectiva. Cíclico, pois descreve experiências vividas nas ruas, que se

\footnotetext{
${ }^{2}$ LÍSIAS, Ricardo. Cobertor de estrelas. Rio de Janeiro: Rocco, 1999.
} 
repetirão outros dias, em outras grandes cidades, debaixo de outras marquises, mas provavelmente passarão despercebidas de muitos. O dia-a-dia da personagem central gira em torno de dormir ("Ainda bem que está quente, então ele pode dormir sem cobertor e sem encostar em ninguém"), acordar muito cedo ("Os melhores dias para acordar são esses, quando alguém dá alguma coisa para comer, porque aí, mesmo que ele não arranje nada o dia todo, não tem problema, porque ele já está forte e vai conseguir correr e segurar tudo."), quando as pessoas começam a movimentar as ruas, e andar. Andar, procurando por comida ( "eles tombam a lata de lixo para ver se tem alguma coisa pra comer. O menino gosta dos doces, sempre tem um pouco no pratinho, às vezes dá pra pegar com o dedo, mas tem uns dias que precisa lamber."), observando as pessoas irem e voltarem, defendendo-se de possíveis investidas da polícia e de civis que o enxergam como uma ameaça ( "um homem bobo falou para ele sair dali porque ele é um cachorro vira-lata."), até que o dia caia, a noite chegue, e ele novamente inicie o ciclo (" Quando esfria demais e ele não consegue dormir, o melhor é ficar andando, porque aí o frio é menor.") (LíSIAS, 1999, p. 25, 26, 19, 34 e 35).

O narrador refere-se à personagem central como "menino", sem um nome próprio, e não há, no livro inteiro, qualquer caracterização física que possa distingui-lo imageticamente das outras personagens secundárias da narrativa. Ele é produto de uma sociedade desigual e negligente, de uma família violenta, como tantos outros meninos que são mencionados na narrativa. Essa ausência de descrição ou diferenciação das personagens por nome desenha dramaticamente o problema social dos meninos de rua, ao colocá-los todos como meninos cujo nome não é relevante, cuja individualidade não está em questão, e são identificados apenas por características físicas genéricas ("o menino", "o grandão", "a menina do nenezinho", etc.).

O menino, por sua vez, também identifica as pessoas à sua volta através de características físicas, tanto meninos de rua ("o menino do narigão", "o menino grandão") quanto personagens que, por estarem em um nível de estratificação social mais elevado na narrativa, poderiam ser apresentados com nome próprio, mas não são ("o padre gordão", as "freiras burras"). Essa questão de ausência de nomes próprios para as personagens talvez indique que o menino não nomeia pessoas com as quais se relaciona por dificuldade de simbolizar as coisas que 0 
cercam, pois a abstração e complexidade em enxergar o mundo com diversos tons e especificidades não é faculdade ainda desenvolvida. Outra possível interpretação é a de que o jogo social no qual ele está inserido não permite que ele se aproxime o bastante das pessoas que se encontram em um nível de estratificação social diferente da dele para que conheça seus nomes, o endereço onde moram, quem são "no papel".

Ao narrar de maneira onisciente, mas com graus variados de onisciência, o narrador ajusta sobre a vida do menino lentes que o põem em evidência. Mesmo sem saber o nome do menino, quem são seus pais ou onde ele mora, o leitor é capaz de criar uma conexão com essa personagem, pois ao longo da narrativa acompanha seu sofrimento, suas vitórias, seu sonhos. O leitor é capaz de estabelecer uma relação emotiva com a personagem, pois aprende como o menino pensa, qual sua lógica interna, por quais experiências passa, o que o entristece, o que o irrita:

\begin{abstract}
O menino está muito nervoso com o padre gordão, porque nunca mais que ele volta. O padre gordão não pode fazer isso, prometeu ensinar a ler e a escrever para ele ficar inteligente e comprar uma casa e depois foi embora. O padre gordão é um mentiroso mesmo, fica inventando um monte de coisas para ele. (...) Bem feito que tem aquela barriga grande e fedida, porque só fica sentado na mesa lendo, sem fazer nada, só pode ficar com aquela barrigona mesmo. (LíSIAS, 1999, p.27).
\end{abstract}

O leitor aprende, por exemplo, que o menino é muito determinado a aprender a ler e escrever o próprio nome (embora, surpreendentemente, o nome que ele aprende a escrever seja "menino"), pois quando o fizer, conseguirá arrumar um emprego, comprar sapatos iguais aos dos homens importantes, comprar uma casa e ganhar dinheiro. Sua maneira fatalista de pensar alfabetização e ascensão social ilustra a ideia freireana de "magicização da palavra" (FREIRE, 1981, p. 27), a qual ainda acaba sendo ensinada como uma fórmula mágica a ser desvendada, codificada, sendo este o objetivo maior do processo de alfabetização. Na narrativa, este é o entendimento que o menino tem de alfabetização, e essa dimensão ingênua das consequências de aprender a escrever o próprio nome serve de cerne para todo o desenrolar da narrativa: "Ele 
ainda não é um homem importante, porque não aprendeu a ler para poder comprar uma casa e um sapato." (LÍSIAS, 1999, p.51).

A inocência da infância (além de outras características, como o imediatismo e o descontrole emocional) ainda está de certa forma preservada na personagem central, e é reforçada pela dificuldade que o menino tem de pensar sobre as coisas de maneira mais complexa. Todas as suas percepções e inferências sobre o motivo pelo qual as coisas acontecem a sua volta são apresentadas através do discurso indireto livre, que apresenta ao leitor sua maneira de pensar, a qual, na maioria das vezes, não inclui diversas possibilidades, previsões ou hipóteses, mas sim uma visão fatalista e sequencial da vida:

\footnotetext{
O menino não sabe o que aconteceu depois, porque ele nunca mais viu aquele menino, vai ver que ele morreu, porque pelo tanto que ele gritava, devia estar doendo muito. Ele não sabe o que acontece quando alguém cai com o pé no fogo, mas ele desconfia que devem cortar fora [...]. Vai ver é por isso que ele nunca mais viu o outro, cortaram o pé e ele não pôde mais andar. (LÍSIAS, 1999, p.34)
}

Essa inocência costura a narrativa, que apresenta sua fantasia acerca da vida social como estratégia inconsciente de sobrevivência, talvez pela sua impossibilidade de compreender a complexa realidade em que está inserido: "Por isso que ele não gosta de deixar o pé para fora do cobertor, porque de noite pode vir alguém puxar, até o bicho-papão, que também faz barulhos com a boca."(LÍSIAS, 1999, p.62).

Sua limitada compreensão de mundo mescla-se com a crueldade da realidade em que vive: a realidade pobre, suja, violenta e desumana das ruas: "Quando acontece igual hoje, não é bom, porque o menino fica com sono e os olhos ficam com muita vontade de fechar. É que ninguém dormiu de noite.", "Ainda bem que aquele outro menino grandão tinha uma faca, porque se o guarda viesse correndo atrás, ele poderia pegar a faca e colocar bem na barriga do guarda." (LíSIAS, 1999, p.42 e 43). Pela falta de conhecimento letrado, o menino descreve suas experiências utilizando palavras e coloquialismos que denotam limitação linguística e limitação na percepção da complexidade social; porém, sua experiência de mundo é grande para tão pouca idade, e isso se reflete na 
pungência com a qual suas descrições possivelmente ferem o leitor (ou seriam as experiências do leitor conversando com a narrativa, e traduzindo-a cortante para sua realidade?):

\begin{abstract}
Ruim mesmo é quando, bem no meio da noite, os meninos grandões seguram no braço dos outros e fazem aquela coisa que dói demais. Teve um dia que até saiu sangue, mas os outros ficaram rindo e jogando o calção do menino de um lado para outro e ficaram falando que ele é mulherzinha. (LíSIAS, 1999, p.99)
\end{abstract}

As lentes do narrador onisciente aumentam e diminuem o poder de visão e conhecimento do leitor; diminuem ao narrar acontecimentos de personagens secundárias, aumentam ao acompanhar a vida desse menino de rua, tão parecido com todos os outros, mas ao mesmo tempo tão singular.

A narrativa é perpassada pela violência, não só a que está explícita nas ruas, mas também a violência latente dentro do próprio menino, que explode em momentos nos quais ele se sente inseguro, injustiçado, sem apoio. Como explica Michèle Petit, a dificuldade de simbolizar sentimentos e experiências se traduz em agressividade: "Quando se é privado de palavras para pensar sobre si mesmo [...], só resta o corpo para falar: seja o corpo que grita com todos os seus sintomas, seja o enfrentamento violento um corpo com outro ". (PETIT, 2008, p.71). Na narrativa, ele entra em ciclos de repetições e xingamentos soltos em seu próprio pensamento que chegam a se esticar por mais de três páginas, quando alguma outra personagem engatilha no menino sentimento de revolta, negação, solidão ou desesperança.

Essa violência simbólica (de certa forma) contida é apresentada através de fluxo de consciência da personagem central através do monólogo interior livre. O fluxo de consciência é um recurso narrativo apropriado para descrever a descarga emocional da personagem ao passar por períodos de frustração e incompreensão dos fatos sobre os quais ele não possui controle algum, é a "apresentação idealmente exata, não analisada, do que se passa na consciência de um ou mais personagens"(CARVALHO, 1932, p.51), como se vê por exemplo neste trecho: 
O menino está muito nervoso com o padre gordão, porque nunca mais que ele volta. $O$ padre gordão não pode fazer isso, prometeu ensinar a ler e a escrever para ele ficar inteligente e comprar uma casa e depois foi embora. O padre gordão é um mentiroso mesmo, fica inventando um monte de coisas para ele. É um tonto, fica só acreditando naquelas histórias e naqueles desenhos e não sabe nada. Bem feito que tem aquela barriga grande e fedida, porque só fica sentado na mesa lendo, sem fazer nada, só pode ficar com aquela barrigona mesmo.

Ele nunca mais vai voltar na igreja, porque o padre mentiu. E nem adianta vir dizendo que tem coisa boa pra comer, porque ele não precisa das coisas do padre. O padre gordão pensa que é melhor que os outros só porque tem um monte de livros e usa óculos. É mesmo um tonto, aliás, vai ver que ele nem sabe ler, por isso não quer ensinar, na verdade, ele inventa um monte de coisas. [...] E é verdade aquilo que os outros meninos falam, o padre não gosta de mulher, por isso que fica só lá, com aquelas velhas feias que usam dentadura. Os meninos falam que debaixo daquela saiona preta, o padre coloca roupa de mulher. É mesmo uma mulherzinha, aquele padre, não precisa voltar mais, porque o menino pode muito bem descobrir sozinho o que está escrito naquela parede do prédio grande da avenida. (LÍSIAS, 1999, p. 27 e 28).

Essa passagem da narrativa ilustra o tipo de fluxo de pensamento por meio do qual se expressa a personagem, um modo que não é todo ordenado, mas associativo; ele associa as supostas mentiras e promessas não cumpridas do padre gordão com sua suposta crença em desenhos e escrituras da bíblia, e com sua suposta incapacidade de ensinar; associa sua constituição física com a oferta de comida às crianças; associa os livros do padre com sua suposta presunção; associa seu celibato (que ele não compreende) com falta de masculinidade. Com exceção da pontuação, há interferência mínima do narrador, que não opina, não corrige as interpretações do menino, não formula suas verdades. O recurso da onisciência seletiva permite ao leitor aproximar-se ainda mais da personagem e partilhar deste momento de profunda frustração.

A complexidade dessa narrativa também deriva da variedade de posicionamentos do narrador, que ora permite traçar um perfil da personagem central, a partir de suas impressões, sentimentos e opiniões acerca de outras personagens e do que acontece à sua volta, ora se distancia do centro, fazendo uma descrição sumária daquilo que acontece ao menino, para então se aproximar novamente. Nos momentos em que descreve ações do menino, entremeando-as com sua apreensão simbólica do mundo, o narrador suscita no leitor a ampliação da percepção sobre o contexto social, extra-literário, sobre outros meninos de rua, inevitavelmente presentes em parques, ruas, calçadas e marquises das grandes cidades: 
Depois de recolher os gravetos e guardá-los na árvore, o menino foi procurar as pedras: as maiores são os ônibus e as menores, os carros. [...] Nos carros, vão todos, os grandes e os pequenos, porque é dia de passear no parque. $O$ menino também vai no parque, algumas vezes, principalmente quando faz sol. (LíSIAS, 1999, p.9).

Pode-se olhar para a construção da personagem central de uma maneira polifônica: o menino é um produto dos muitos discursos e vozes que o atravessaram, e assim são suas crenças sobre a vida, trabalho, família, escola, dinheiro. Sua percepção sobre o mundo é perpassada por imagens de homens indo e voltando do trabalho, calçando sapatos que cobrem a suposta sujeira de seus pés, por mulheres que lhe negam o lanche e o chamam de cachorro viralata, por promessas irrealizadas de uma vida melhor como decorrência da aprendizagem da leitura e escrita.

Para o menino, esses acontecimentos estão atados e acontecem cronológica e hierarquicamente: ingenuamente, ele acredita que, se souber escrever seu nome, saberá ler os livros da livraria e ficará muito inteligente, poderá arrumar um emprego e comprar sapatos, e depois uma casa, na qual ele irá morar, fazer bolos e receber visitas. Esse desencadear de consequências não acontece, o que frustra sua tentativa de ser como as pessoas que ele deseja ser, as que passam no parque todas as manhãs e tardes:

\footnotetext{
Aí o menino ficou muito nervoso, porque o padre gordão é um mentiroso, ele fala as coisas e depois, na verdade, são outras coisas que acontecem. Primeiro, ele falou que o menino tinha que aprender a escrever o nome, mas agora, ele diz que para escrever uma carta, tem que aprender um monte de outras letras para juntar e isso leva muito tempo. Quer dizer que para arranjar um emprego que paga no final do mês e comprar a casa ainda vai demorar. Então, o menino vai ter que ficar ainda dormindo lá no viaduto, mesmo depois de ter estudado todo aquele tempão. (LíSIAS, 1999, p.126)
}

Nessa narrativa, a dificuldade de compreensão ampla do mundo é causa e consequência da dificuldade de simbolizar, de compreender o mundo e a si mesmo; a partir dela, leitores são convidados a reavaliarem a problemática social ali representada a partir do olhar atento que é dado à vida e aos problemas enfrentados por pessoas que são tratadas como desprovidas de humanidade e de 
cidadania, pessoas que habitam as ruas de qualquer grande cidade. Ao voltar-se para a figura do menino e debruçar-se sobre como ele pensa, o que sente, como se relaciona com as pessoas e com o mundo, a narrativa nos faz perceber essa personagem que é desprovida de nome próprio, mas provida de vivências cheias de dor e significado. Sem ser explicitamente pedagógica nem moralista, mas sendo densa e artisticamente construída, a narrativa também convida os leitores a avaliarem a sociedade em que vivem, e, dentro dela, sobretudo o valor que se dá ao direito de ler e interpretar palavras e o mundo, de grafar o próprio nome e se sentir parte da sociedade.

A leitura dessa narrativa dentro ou fora da escola suscita a possibilidade de os leitores perceberem um grupo que, apesar de ser facilmente localizado nas ruas das cidades, vive em um mundo que faz questão de torná-los invisíveis ou, quando visíveis, temíveis, inferiores, desprezíveis. "A leitura, na realidade, é uma promessa de não pertencer somente a um pequeno círculo." (PETIT, 2008, p.96). Nesse sentido, a leitura de obras pungentes como essa, que simbolizam aspectos fulcrais da sociedade contemporânea, dá a oportunidade ao o leitor de perceber, sentir, pensar e ressignificar o complexo mundo em que vive, rompendo sua (eventualmente) também ingênua e limitada forma de perceber a si e aos outros.

\section{Espaços em Each Kindness, por Jacqueline Woodson}

Escrita em outro gênero e num país com outros indicadores sociais, Each Kindness ${ }^{3}$ é, como dissemos, uma narrativa infanto-juvenil que conta a história de Maya, uma menina recém transferida para uma nova escola, a partir da perspectiva de outra (Chloe), que já se sentia pertencente àquele espaço. Os temas sociais e universais abordados nessa obra, como bullying, exclusão social, sentimento de não pertencimento, são abordados não de maneira direta e óbvia, mas costurando os acontecimentos através de recursos literários que contribuem para um efeito denso e impactante. Como afirma Antonio Dimas, "Entre as várias armadilhas virtuais de um texto, o espaço pode alcançar estatuto tão importante quanto outros componentes da narrativa." (DIMAS, 1987, p.5). Esta análise

\footnotetext{
${ }^{3}$ WOODSON, Jacqueline. Each Kindness. Nova lorque: Penguin Putnam Inc, 2012. [O livro ainda não tem tradução no Brasil.]
} 
pretende destacar alguns aspectos referentes à descrição do espaço para a criação de uma ambientação narrativa que emoldura e define o tom de todo 0 desenrolar da trama, bem como a utilização do que Tomachévski (apud DIMAS, 1987) chama de "motivos associados, marginais e falsos" para o desenho artístico da narrativa.

Maya é uma aluna nova que entra na sala de Chloe e que, pela maneira que se veste e de como se parece, começa a sofrer bullying. É uma narrativa que traz os temas da pobreza, da exclusão social, do preconceito:

Every day, we whispered about Maya, laughing at her clothes, her shoes, the strange food she brought for lunch. [...] I have a new name for her, Kendra whispered. Never New. Everything she has came from a secondhand store. (WOODSON, 2012, s/p.)

A descrição de sua primeira aparição na escola é acentuada pela maneira como a narradora - nesse momento atuando como "eu testemunha" (LEITE, 1987) - faz uma varredura dos pés à cabeça de Maya, percebendo o que Maya está fazendo com sua cabeça, até a fivela do sapato que está estragada: "Maya looked down at the floor. [...] Her coat was open and the clothes beneath it looked old and ragged. Her shoes were spring shoes, not meant for the snow. A strap on one of them had broken". (WOODSON, 2012, s/p.). A ambientação é feita de maneira reflexa, isto é, "as coisas, sem engano possível, são percebidas através da personagem." (apud DIMAS, 1987, p.22). Essa descrição, inclusive, logo ao início da narrativa, é decisiva, pois define as lentes através das quais as outras personagens e também o leitor enxergarão Maya: como a menina nova, tímida, que não possui roupas novas nem sapatos adequados para o inverno.

Em relação ao grande espaço onde a narrativa se desenvolve, não se informa a cidade ou país no qual a história se situa, o tamanho da escola ou o número de alunos, nem tampouco a idade exata das personagens. Sabe-se, contudo, que a história se situa em algum lugar do mundo onde neva durante 0 inverno, e onde pessoas são julgadas pelas roupas que usam. A indefinição desses elementos permite o tratamento de um tema de grande alcance, talvez universal: a exclusão e o julgamento de uma criança por um grupo pré- 
estabelecido, por motivos sociais (renda e aparência), o que a impede de criar laços de amizades e de se sentir pertencente ao novo espaço.

A narrativa começa durante o inverno, quando neva. A passagem do tempo e das estações é simbólica para a narrativa, uma vez que as personagens também evoluem com o passar do tempo, das estações. É o que Tomachévski chama de motivação caracterizadora, que "deve ser entendida como a que confirma um estado de coisas ou a ele se opõe. Pode ser-lhe homóloga ou heteróloga." (DIMAS, 1987, p.37). Em outras palavras, ele será homólogo se a caracterização do espaço estiver em consonância com o desenrolar da trama (por exemplo, um dia de sol para personagens felizes) ou heterólogo, se a caracterização vai contra o que acontece na história (por exemplo, um dia de chuva para personagens tristes). O aspecto do tempo pode ser tomado como homólogo ou heterólogo nesta narrativa, a depender da perspectiva que se toma. Ao olhar pela perspectiva de Maya, a caracterização do tempo é homóloga, pois há uma evolução em sua atitude em relação às crianças de sua nova escola. No início da narrativa, Maya chega a esse novo espaço frio, gelado pela neve ("That winter, snow fell on everything, turning the world a brilliant white."), e faz várias tentativas sem sucesso de se enturmar ("I moved my chair, myself and my books a little farther away from her. When she looked my way, I turned to the window and stared out at the snow."). Após tentativas frustradas de ser incluída no grupo ("Whenever she asked us to play, we said no."), Maya desiste de tentar se incluir e passa a brincar consigo mesma no recreio. (WOODSON, 2012, s/p.). Contrastivamente, se a neve é para todos, as brincadeiras infantis não o são; se o mundo se tornou brilhante pela brancura da neve, a solidão de Maya parece despejar sobre ela uma cor mais sombria. Em seguida, vem também a mudança para uma nova estação do ano:

The days grew warmer and warmer. The pond thawed. Grass began growing where snow had once been. [...] Maya stood by the fence. She was holding a jumping rope but did not come over to ask us if we wanted to play. After a while, she folded it double, rolled the ends around each hand and started jumping. She jumped around the whole school yard without stopping. She didn't look up once. (WOODSON, 2012, s/p.) 
A mudança no tempo, mais precisamente na temperatura que, aliada ao espaço ajuda a criar diferentes ambientações para a narrativa (mais amena, depois mais quente) também acontece no desfecho da narrativa, quando Chloe se arrepende pela falta de gentileza com a qual tratara Maya, e percebe que não terá uma chance para reparar o seu erro, pois essa chance já se foi, assim como o dia que também terminava: "I watched the water ripple as the sun set through the maples and the chance of a kindness with Maya became more and more forever gone." (WOODSON, 2012, s/p.).

Maya não consegue ser aceita por aquela comunidade, apesar de inúmeras tentativas de negociação e aproximação social, através do compartilhamento de brincadeiras e brinquedos que representam a sua própria identidade e cultura. Maya é sempre associada à figura da criança estrangeira, que não possui lugar no espaço já colonizado por uma cultura pré-estabelecida, por um grupo que se considera dominante. Um recurso de caracterização das personagens desta obra, que se associa com a ambientação, é a repetição de certos comportamentos, que passam a ser representativos dessa relação entre Maya e as outras crianças: as mãos de Maya, sempre abertas e receptivas, contrastam com as mãos de Chloe, que se fecham quando ela percebe ser incapaz de ser gentil. Os momentos da narrativa em que Maya tenta chamar a atenção de outras crianças para brincar com ela são sempre evidenciados por suas mãos:

She held her open hand to show us the shiny jacks and tiny red ball she'd gotten for her birthday. [...] Some days, Maya held out her hand to show us what she had brought to school - a deck of cards, pick up sticks, a small tattered doll. (WOODSON, 2012, s/p.)

Os dois momentos nos quais Chloe se dá conta da sua falta de gentileza com Maya também são simbolizados pelas mãos de Chloe que, ou se mantém fechada, imóvel ("I stood there, holding Ms. Albert's rock in my hand, silent."), ou é aludida através da lembrança que Chloe tem das vezes em que Maya estendeu sua mão e ofereceu brinquedos a ela, e ela recusou: "Like each kindness - done and not done. Like every girl somewhere - holding a small gift out to someone and that someone turning away from it."(WOODSON, 2012, s/p.). 
Após várias semanas - o que se constata pela passagem do inverno para a primavera - Maya pára de fazer tentativas de construir novos laços de amizade, até que um dia vai embora para sempre e deixa uma marca eterna em Chloe: "Maya didn't come to school the next day. Or the day after that. Each morning, I walked to school slowly, hoping this would be the day Maya returned and she'd look at me and smile. I promised myself this would be the day I smiled back." (WOODSON, 2012, s/p.).

O livro trata de exclusão de uma maneira poética e contundente, e não oferece um final feliz; Chloe, apesar de se arrepender por ter sido injusta e cruel com Maya, não tem a oportunidade de se redimir com ela, e tem que aprender a viver com esse sentimento de arrependimento, por não ter sido uma pessoa melhor para a menina. É o que Tomachévski chama de "motivação falsa ou de despistamento, quando "o autor nos permite supor um falso desfecho" porque estamos habituados a "interpretar cada detalhe da obra de maneira tradicional" (apud DIMAS, 1987, p.37). Em livros infanto-juvenis não seria inusual se uma lição de moral resultasse de um final feliz. Como comenta Dimas sobre motivação falsa na narrativa, este é um caso no qual "um determinado conjunto de motivos já se cristalizara e se convencionalizara a ponto de condicionar o leitor ou espectador." (apud DIMAS, 1987, p.38). Afinal, o livro representa situações diante dos quais adultos responsáveis por criar uma criança esperariam que ela agisse de modo exemplar ; logo, espera-se que Chloe se arrependa de suas ações (o que realmente acontece, embora tardiamente) e que mostre esse arrependimento e seu caráter restaurado de menina que sabe ser gentil com todas as crianças (o que não acontece, pois Maya vai embora da escola).

Essa motivação falsa é ambientada e adensada a partir do recurso estilístico da repetição; assim como a pedra que, ao ser jogada na água produz consequentemente ondas que vão se dissipando do centro para fora, assim como cada pequeno ato de gentileza gera outro ato de gentileza, segundo Ms. Albert na narrativa para seus alunos, também se comportam as palavras nessas cenas: se movem de maneira repetida e uniforme: "Ms. Albert had brought a big bowl into class and filled it with water. We all gathered around her desk and watched her drop a small stone into it. Tiny waves rippled out, away from the stone. "This is what kindness does", Ms. Albert said." E depois no desfecho: "I threw the small 
stones into it, over and over. Watching the way the water rippled out and away. Out and away. (...) I watched the water ripple as the sun set through the maples and the chance of a kindness with Maya became more and more forever gone." (WOODSON, 2012, s/p.) No desfecho, o efeito da pedra na água é diferente do efeito que Ms. Albert pretendia produzir em seus alunos, pois o que se dissipou em pequenas ondas foi a chance de Chloe conseguir se redimir com Maya; essa chance foi ficando cada vez mais distante e inatingível.

Todos esses detalhes e recursos empregados na narrativa the conferem autenticidade e densidade, produzindo significado e sendo necessários para a narrativa, "na medida em que [...] são capazes de instaurar uma "cumplicidade rítmica entre o clima físico e o clima humano dentro da obra". (apud DIMAS, 1987, p.36). Essa obra literária deixa de ser somente uma desculpa para ensinar às crianças o certo e errado, e passa a ser uma experiência rica em elementos a serem sentidos e tomados como objeto de reflexão.

A análise do espaço associada à caracterização das personagens dá a possibilidade de os leitores darem um passo a mais e olharem mais de perto a obra, analisando como as escolhas da autora intensificam o efeito derivado da reflexão sobre o social, neste caso representado pela interação conflituosa entre crianças.

Potencialmente, muitas crianças de culturas diversas poderão se identificar com a trama, pois trata de temas universais, como sentimento de pertencimento a um grupo, construção de identidade por meio de relações sociais, amizade, arrependimento, culpa. Também trata de pobreza, diferenças sociais, preconceito. Segundo Petit, " a leitura pode ser uma via privilegiada para inventar um caminho singular, para construir uma identidade aberta, em evolução, não excludente." (PETIT, 2008, p.73). Logo, dar a oportunidade para leitores infantis sentirem e refletirem sobre sensações de desconforto, surpresa, (des)contentamento, reflexão, curiosidade e questionamentos por meio da ficção é dar a elas a oportunidade de se descobrirem enquanto seres humanos e enquanto seres sociais.

\section{Pensar sobre palavras e sobre o mundo}


Nas palavras de Antonio Candido, "Uma sociedade justa pressupõe o respeito dos direitos humanos, e a fruição da arte e da literatura em todas as modalidades e em todos os níveis é um direito inalienável." (CANDIDO,1988, p.191). Uma sociedade justa, portanto, não pode prescindir da literatura - e das artes - como um direito tão inalienável quanto o direito à comida e à moradia, pois a literatura dignifica, ressignifica e pensa o ser humano - convidando-o, assim, a se repensar.

As análises feitas aqui são amostras das perspectivas que podem ser tomadas dentro de uma proposta escolar de leitura. A leitura de textos literários é poderosa oportunidade de diálogo e reflexão acerca do mundo, de como ele se estrutura hierarquicamente e como essa estrutura poderia ser outra. Pensar sobre o mundo e sobre si próprio enquanto indivíduo e membro de uma comunidade é exercício a ser praticado desde cedo, e o espaço escolar possibilita esse tipo de reflexão por meio da literatura e de outras artes.

Ao tomar o momento da leitura como oportunidade de construção de cidadania, dá-se aos alunos as condições de reconhecerem injustiças e de perceberem que "antes de pertencer a este ou àquele território, somos todos seres humanos." (PETIT, 2008, p.93). Essa ascensão da consciência de ser humano enquanto ser social pode ser atingido através de uma leitura minuciosamente planejada, como proposta aqui, na qual os alunos também tomam consciência do fazer literário, que não é aleatório, que faz uso de elementos narrativos e semióticos a fim de evidenciar conceitos, sensações e emoções de maneira pungente, passando a obra literária a ter diversas funções: para entretenimento pessoal ou de um grupo, para estudo de língua e expressividade, para reflexão e provocação social, para ser mais uma forma de questionamento da organização do mundo.

\section{KNOWING HOW TO READ BOOKS (AND THE WORLD) IS A LIBERATING SKILL}

\footnotetext{
Abstract: This article aims at emphasizing the importance of reading the world as a literacy component, being an important tool for building critical citizens who understand the world and their role in it. This reflection is made through the literary analysis of two narrative pieces, Cobertor de Estrelas, by Ricardo Lísias and Each Kindness, by Jacqueline Woodson, having as a main focus the textual elements narrator and space. The analysis showcase samples of perspectives that
} 
might be undertaken in a school reading proposition, as reading literary texts is a powerful opportunity for dialogue and reflection about the world, how it is hierarchically structured and how that structure might be different.

Key words: literacy. literary analysis. reading the world.

\section{Referências bibliográficas}

CÂNDIDO, Antônio. O direito à literatura. In: Vários escritos. São Paulo e Rio de Janeiro: Ouro sobre Azul, 2004. p. 169-181.

CARVALHO, Alfredo. Foco narrativo e fluxo da consciência: questões de teoria literária. São Paulo: Pioneira, 1932.

DIMAS, Antônio. Espaço e romance. São Paulo: Editora Ática., 1987.

FREIRE, Paulo. A importância do ato de ler. São Paulo: Cortez, 1981.

KRESS, Gunther.; LEEUWEN, Theo. Reading Images: The Grammar of Visual Design. USA and Canada: Routledge, 2006. 2 ed.

LEITE, Lígia. O foco narrativo (ou A polêmica em torno da ilusão). São Paulo: Ática, 1987.

LÍSIAS, Ricardo. Cobertor de estrelas. Rio de Janeiro: Rocco, 1999.

LLOSA, Mario. "É possível pensar o mundo sem o romance?". In: MORETTI, F. (org). A cultura do romance. CosacNaify: 2009. p. 17-32.

PETIT, Michèle. Os Jovens e a leitura. Uma nova perspectiva. São Paulo: editora 34, 2008.

SOARES, Magda. Letramento: um tema em três gêneros. Belo Horizonte: Autêntica, 2003.

WOODSON, Jacqueline. Each Kindness. Lewis. Nova lorque: Penguin Putnam Inc, 2012. 